et Géophysique. Après intervention de MM. Bianchi, Esclangon, Silva, A. Lambert, Dyson, Witkowski, Banachiewicz, Schlesinger, Général Perrier, Nörlund, les résolutions suivantes sont finalement adoptées.

(I) “ La Commission del'Heure propose à l'unanimité qu'une subvention annuelle de 40,000 francs français soit accordée au B.I.H. jusqu'à la prochaine Assemblée Générale. La Commission compte que l'insuffisance de cette allocation pour assurer la bonne marche du Bureau, dont le rôle essentiel et indispensable est reconnu par tous, pourra être corrigée grâce à l'aide financière de l'Union Géodésique et Géophysique, à partir de janvier r933."

(2) “La Commission de l'Heure propose à l'unanimité que le déficit budgetaire subi cette année par le B.I.H. en raison de la dépréciation de la livre soit comblé par une subvention supplémentaire exceptionnelle de roo livres."

(d) La Commission accepte que le Bureau de l'Heure reprendra au vœu exprimé à Stockholm, lors de la dernière Assemblée de l'Union de Géodésique et Géophysique; le Bureau de l'Heure se chargera de centralisation et de discuterl'ensemble des mesures qui seront effectués lors de l'opération mondiale des longitudes de I933.

(e) Après un court exposé de M. Jouaust sur les erreurs à craindre dans l'enregistrement des ondes qui ne présentent pas un front raide et sur la mesure des retards des appareils enregistreurs de signaux horaires, la Commission adopte les deux vœux suivants:

(I) "Il est désirable que les signaux horaires scientifiques soient émis par les postes à arc ou à lampes à l'exclusion des postes à alternateur."

(2) "Il est tout à fait utile que chaque émission de signaux horaires scientifiques soit suivie d'un trait long d'une durée minimum de ro secondes, afin de permettre l'évaluation, par un procédé très simple, des retards dans les enregistrements de signaux."

(f) Lecture est donnée par la Président de deux propositions de M. Sôtome arrivées après l'impression de l'ordre du jour:

(I) "In view of the probability that the continents and islands may have each a different tendency of drift on the surface of the earth, it seems to be reasonable to locate the site of the prime meridian at an adequate spot in the continents."

(2) "Immediate abolition of the Summer Time."

La Commission a examiné ces propositions avec intérêt, mais estime qu'elle ne peut, pour l'instant, entreprendre aucune action dans ce sens.

\title{
Commission 33. (StellaR Statistics.)
}

Acting President: Dr J. H. Oort.

Secretary: Prof. B. Lindblad.

A few questions relating to the observing programme of parallax observers and to catalogues of proper motions for fainter stars were discussed and the following recommendations were passed:

(I) "That parallax observers are requested to publish the basis of selection of the stars of their observing programmes."

(2) "That the authors of lists of large proper motions should give more attention 
to the problem of identifying difficult and interesting stars (for instance by sketches of the surroundings)."

Prof. K. Lundmark presented the extensive new tables for deriving galactic co-ordinates with an accuracy of $0^{\circ}$.OI prepared at the Observatory of Lund in accordance with the recommendations of the Union at the meeting in Leiden.

The Chairman returned the thanks of the Commission to Prof. Lundmark.

The Harvard pole of the galactic circle, $\alpha \times 12^{\mathrm{h}} 40^{\mathrm{m}}, \delta=+28^{\circ}$ (I900), has been used for the tables in question. The Commission resolved to make the following recommendation:

(3) "That the Harvard pole of the galactic circle be used for defining galactic co-ordinates, when special reasons do not make an adoption of a different pole desirable."

\section{Commission 34. (SOlaR Parallax.)}

Acting President: Prof. Schlesinger.

SECRETARY: Mr Horrocks.

In adopting the Draft Report as drawn up by the President of the Commission the meeting recorded its indebtedness to $\mathrm{Dr}$ Spencer Jones for his labour in framing it.

It was resolved to request the executive committee to make a grant of 2500 Swiss francs annually to the Solar Parallax Commission until the next meeting of the Union.

Prof. Kopff regretted that the results of the meridian observations made at Besançon and Rome could not be used in the formation of the Catalogue of Primary Reference Stars as these were received too late for inclusion.

The Commission endorsed the recommendation contained in the report that observatories should communicate without delay the lists of secondary comparison stars whose positions are required for the reduction of Eros plates of small field. It was pointed out that in the case of southern reference stars (south of dec. $-\mathrm{r}_{4}^{\circ}$ which is the limit of Prof. Schorr's list) the final list of stars for measurement depended solely on such communication of requirements.

It was recommended that the standard co-ordinates of secondary comparison stars on plates taken, as well as their right ascension and declination, should be published by the observatories which have taken plates for the determination of their positions.

The meeting closed with a general discussion of systematic errors due to differential atmospheric dispersion.

\section{Commission 35. (STEllar Constrtution.)}

President: Prof. Sir Arthur Eddington.

Secretary: Prof. H. N. Russell.

The report of the Chairman was approved and accepted as printed. 